\title{
Democracy in the New Towns: The Limits of Private Government
}

The Engineering News Record of December 7, 1967 reports that private enterprise is planning a new city for rural Minnesota. The city will be self-sufficient for its 250,000 residents. It will be covered by a large dome to provide a pleasant climate year-round. The planners are studying the feasibility of "a new kind of corporate city administration" which might involve selling shares in the city. ${ }^{1}$

The "New Town" movement has arrived in the United States. One recent estimate placed the number of current new communitiesdevelopments of at least one thousand acres planned for a minimum of three to four thousand residents and sufficient supporting facilities, activities, and uses to constitute a complete community-at from 200 to $250 .{ }^{2}$ Not all of these communities, however, will be New Towns in the classic sense. ${ }^{3}$ Some are nothing more than prosaic subdivisions on a large scale; others are bedroom communities; and still others are special purpose towns-retirement cities or recreational communities.4 The "true" New Town-the subject of this commentis not only large in terms of population and geographical area, ${ }^{5}$ but attempts to reflect the full diversity of urban life, providing a mixture

1 Encineering News Record, Dec. 7, 1967, at 21.

2 NOREN, NEW TOWNS IN THE UNITED States 5 (National Association of Home Builders Land Use and Development Department, 1967). Fortune estimated that over 140 New Towns were under construction in 1966. What's New About New Towns, Fortune, Feb. 1966 , at 158 .

3 The idea of the New Town was first presented in its modern form by Ebenezer Howard in his 1898 text now available under the title Garden Cities of To-Morrow (1965). The movement has been kept alive in the United States by a small group of planners and urban critics, foremost of whom have been Clarence S. Stein, author of Toward New Towns For America (1951), and Lewis Mumford. For analyses of New Towns in England and Canada, see L. Rodwin, THE BRITIsH NEw Towns Policy (1956); Comment, The Administration of the English New Towns Program, 1965 WASH. U.L.Q. 17; Oberlander \& Oberlander, Canada's New Towns, 37 Prog. ARch. 113 (1956).

4 What's New About New Towns, Fortune, Feb. 1966, at 158. See also Advisory Commission on Intergovernmental Relations, Urban and RuRal AMErica: Policies for FuTURE GROWTH 77-8 (1968) [hereinafter cited as ACIR].

547 developments underway in March 1968 ranged in size from 1,000 to 101,120 acres and in predicted population from 10,000 to 600,000 , with an estimated total population of nearly 2,500,000. ACIR at 78, Table 41 (retirement communities excluded). 
of jobs, housing, and recreation which will appeal to the widest possible range of people. ${ }^{6}$ Nearly fifty such towns are currently being developed. ${ }^{7}$

Because of the number of people who will eventually live in New Towns, the implications of the governmental arrangements being planned for these communities are vast. Compared to the New Towns being built around the world, the most striking thing about the American venture is that our New Towns are being planned and built by entrepreneurs, with little governmental support, guidance, or control..$^{8}$ Each New Town offers its developer the opportunity to imprint his personality ${ }^{9}$ upon the lives and institutions of from 10,000 to 600,000 human beings. For better or for worse, the New Town developer has the power to create and mold living communities.

The belief is common today that government is "beyond the threshold of participation."10 Commentators have called for "decentralization" and "participatory democracy."11 Cities such as New York have already begun to experiment with these ideas in a limited way. But if we are seeking test tubes to help us deal with the old and fundamental "problem of the appropriate unit for a democratic political

B Such New Towns need not be independent of existing metropolitan complexes; rather, they meet the criteria established by the Advisory Commission on Intergovernmental Relations for its report on "new communities" (supra note 4):

"[N]ew communities" are large-scale developments constructed under single or unified management, following a fairly precise, inclusive plan and including different types of hoụsing, commercial and cultural facilities, and amenities suffcient to serve the residents of the community. They may provide land for industry or are accessible to industry, offer other types of employment opportunities, and may eventually achieve a considerable measure of self-sufficiency. With few exceptions, new communities under development today are within commuting distance of existing employment centers.

Id. at 64 (italics omitted).

7 Id. at 77 .

8 The New Communities Act of 1968, P.L., 90-448, Title IV, 82 Stat. 514, which permits the Department of Housing and Urban Development to guarantee obligations issued by developers of new communities up to fifty million dollars per project, sets no standards for local government. However, before making a commitment to guarantee, the Secretary must be determine that "there is a sound internal development plan for the new community which ... is acceptable to the Secretary as providing reasonable assurances that the development will contribute to good living conditions . . . Id. at $\S 404$.

9. On the importance of the developer's personality traits and ideological beliefs, see Kaplan, The Roles of Planner and Developer in the New Community, 1965 WASH. U.L.Q. 88."

10 Dahl, The Gity in the Future of Democracy, 61 AM. PoL. Scr. Rev. 953, 967 (1967).

ii See, e.g., Goodwin, The Shape of American Politics, Commentary, June 1967, at 25, 36-7. On the growing concern for decentralization, see Babcock \& Bosselman, Citizen Participation: A Suburban Suggestion for the Central Gity, 2 LAND-Use ConTrols 21 (1968); L: Mumford, The Urían Prospect 20, 72 (1968). 
system,"12 the New Towns offer what may be our best opportunity for experimentation. If the New Towns can do no better than create institutions which "will produce a disastrous alienation from the political system,"13 the ideal of grass-roots democracy may have reached an insurmountable impasse.

The obstacles are impressive. As one observer concluded:

The fact is, one cannot easily imagine what kind of politics can emerge when the New Towns have been developed. Once the basic decisions have been built in, what will the New Town governments decide-except perhaps the date of the local beauty pageant, or whether to rename a few boulevards? ${ }^{14}$

The most challenging barrier to healthy community ${ }^{15}$ and political life in the New Towns, however, will not be boredom, but paternalism. With such huge corporations as Gulf Oil, Humble Oil, and Goodyear Tire and Rubber ${ }^{16}$ entering the New Town field, the image of company towns is not to be dismissed too easily. "Company paternalism," in fact, has proved to be the outstanding thorn in Canada's

12 Dahl, supra note 10, at 953 .

13 Hanson, Washington: Are Our Counties Ready for Metropolis?, THE WashrngToNIAN, Feb. 1966, at 10, 11.

14 Roszak, Life in the Instant Cities, THE Nation, March 13, 1967, at 396, 340. This is a critical description of life in Valencia and Foster City, two growing California New Towns. See also J. Jacobs, The Death and Life of Great American Cimes 17 (1961).

15 A brief review of the "community" literature may be found in Swanson, The Concern for Community in the Metropolis, I URBAN AFFAIRS Q. 33 (June 1966). Note that two important aspects of democracy in the New Towns will not be discussed in this comment. For analyses of the interplay between a New Town and the pre-existing jurisdiction onto which it is grafted, see E. EIchLER \& M. KApLAN, The Community BuILDERs (1967); Scott, Urban Growth Challenges New Towns, 48 PUblic Management 253 (1966); Mandelker, Some Policy Considerations in the Drafting of New Towns Legislation, 1965 WASH. U.L.Q. 71. On the question whether the New Towns will in fact be able to absorb a significant number of lower-income residents, see EIcHLER \& KAPLAN, supra; Cox, Dream City (Almost), Commonweal, Jan. 20, 1967, at 426; Simon, Reply to Cox, Commonweal, Mar. 3, 1967, at 681; 90th Cong., 2d Sess., House Comm. on Banking \& Currency, Subcomm. on Housing, Housing and Urban Development Legislation and Urban Insurance, Hearings on H.R. 15624, H.R. 15625 and Related Bills, pt. 2, at 747 (statement by Jack Conway) and 975 (statement by James Rouse) (1968). See also N.Y. Times, Jan. 1, 1967, \& 8, at 1 .

16 These corporations are developing Reston; Clear Lake City, Texas; and Litchfield Park, Arizona, respectively. Westinghouse, General Electric, American-Hawaiian Steamship Lines, and a number of other corporate giants are also building New Towns. See Ridgeway, New Cities Are Big Business, NEw Republic, Oct. 1, 1966, at 15. See also ACIR at 80-2. 
New Town experience. ${ }^{17}$ However, unlike the Canadian New Towns and unlike our historic company towns, ${ }^{18}$ our New Towns will be multi-industrial. The threat of economic domination by the town's largest employer is not as real as the threat of developer paternalism. Reston, which Wolf Von Ecbardt has said "promises to be one of the first modern communities in America worthy of the name,"19 has already been written off by a critic as being no more than a "fiefdom."20

This comment analyzes the problem of how New Towns are to be governed. Focusing on two of the most publicized New TownsReston, Virginia, and Columbia, Maryland-it describes the institutions of "private government" which these towns will employ and attempts to evaluate the appropriateness of these institutions. Finally, the comment explores the possibility that these "private governments" may have to be altered or abolished if the requirements for equal voting rights under the fourteenth amendment to the Constitution are to be satisfied.

\section{Government by Contract-An Outline of the Homes Association}

The basic unit of organization in Reston and Columbia is the "homes association"21_an incorporated, non-profit organization that operates under recorded land agreements for the maintenance of private and common property and the provision of certain municipaltype services. The idea of the homes association is more than a century old, ${ }^{22}$ but it has been used frequently only since the advent of the suburban subdivision. In 1962, over 470 subdivisions were organized this way. ${ }^{23}$ The best known example of the homes association, no doubt, has been the one installed at Radburn, New Jersey, the influential model community planned by Clarence Stein and Henry Wright in the late 1920 's. ${ }^{24}$

\footnotetext{
17 McFarland, The Administration of the Alberta New Towns Program, 5 DuQuesne U.L. REv. 377 (1967).

18 On the company town model of private government, see Davis, Company Towns, 4 Encyc. of the Soc. ScI. 119 (1931); J. Reps, The Making of Urban America, ch. 15 (1965); A. Lindsey, The Pullman Strike, ch. 4 (1942).

10 The Community: Could This Be Our Town, New Republic, Nov. 7, 1964, at 17.

20 Viorst, Reston, Horizon, Autumn 1967, at 35.

21 The best source, by far, for information on homes associations is URBaN LAND INstitute, The Homes Association Handbook (1964) [hereinafter cited as ULI HaNDBook]. 22 See Tulk v. Moxhay, 2 Phillips 774 (1848).

23 Foreword to ULI HANDBook at vi.

24 For full descriptions of Radburn by its planner and by the draftsman of the Radburn covenants, see SteIN, supra note 3; C. Ascher, Private Covenants in Urban Redevelopment, in Urban Redevelopment: Problems and Practices 278-309 (C. Woodbury ed. 1953). The Radburn covenants are available in A. Dunham, Modern REAL Estate Trans. ACTIONS 129-47 (2d ed. 1958).
} 
In communities like Radburn, Reston, and Columbia, the establishment of a homes association takes place in four steps. First, the developer prepares and records the final plat of the development. Second, he writes and records a declaration of covenants and restrictions applicable to the entire parcel of land. This declaration becomes the basis of the homes association, setting forth affirmative and negative covenants, easements, liens, and charges which will bind every purchaser of the land. Third, after the declaration is recorded, the developer prepares the articles and bylaws of a homes association, and incorporates the association. Fourth, and only after the other steps have been completed, the developer conveys sections of the land, using a deed which confirms the rights and duties set forth in the recorded declaration.

By the doctrine of reciprocal negative easements, ${ }^{25}$ as soon as the first lot is subjected to the restrictions in the recorded declaration, the rest of the land is automatically bound by the same restrictions. Each purchaser, therefore, has an interest in every other purchaser's deed, and the homes association, as agent and representative of the lot owner, ${ }^{26}$ is the mechanism for insuring that all lot owners remain effectively bound by the covenants and restrictions.

The covenants and restrictions generally run with the land;27 the homes association and individual home owners have the power to sue to enforce both affirmative promises (to pay assessments, for example) and negative promises (such as not to build without the approval of an architectural committee). The association owns and manages open spaces and common property conveyed to it by the developer and performs various services for the lot owners. The individual lot owner and his family have the right to use the association's property, and the owner has a vote in association affairs; in return, he and his family are obligated to pay the association's assessment and to abide by its rules.

The homes association is a favored device for the organization of subdivisions. Pre-existing local governments tend to approve of it because the association performs municipal-type services, assures that common open spaces will be permanent, and guarantees that maintenance will be paid by the benefited properties, rather than from

25 See Turner v. Brocato, 206 Md. 336, 111 A.2d 855 (1955); Sanborn v. McLean, 233 Mich. 227, 206 N.W. 496 (1925).

26 Merrionette Manor Homes Improvement Ass'n v. Heda, II Ill. App. 2d 186, 136 N.W.2d 556 (1956).

27 See Wehr v. Roland Park Co., 143 Md. 384, 122 A. 363 (1923); Dunham, Promises Respecting the Use of Land, $8 \mathrm{~J}$. LAw \& Econ. 133 (1965); Note, Affirmative Duties Running With the Land, 35 N.Y.U.L. REv. 1344 (1960). 
public funds. ${ }^{28}$ The developer favors the homes association because it permits him to maintain a large portion of control during the developmental period, ${ }^{29}$ while allowing him gradually to develop residential participation and responsibility, so that he may eventually withdraw from the project, confident that his community-building reputation will not be injured by the future disintegration of his work.

It can be argued that the homes association in a New Town setting is more than a private corporation-that it is actually a unit of government similar to a municipal corporation. In fact, the descriptive term "government by contract," which applies to Reston and Columbia, was used by Charles Ascher with reference to Radburn, ${ }^{30}$ and it is useful, before discussing in detail the Columbia and Reston schemes, to turn briefly to Radburn, both as the forerunner of more recent New Towns and as an explicit example of private government. The socalled "Green Book," which was given to prospective Radburn residents, contains the following summary:

Since the Radburn Association is undertaking activities so much like those of a municipality, the Association has been organized on the model of the best modern practice in municipal government, and the scheme of organization provides for a President and Trustees (corresponding to a Mayor and Council) who are responsible for determining the policies of the Association; and the actual administration is placed by the By-Laws in the hands of a Manager (corresponding to a City Manager), who is chosen by the Trustees solely on the basis of his executive and administrative qualifications, and who is responsible for the carrying out of the policies of the Trustees. $^{31}$

Early incorporation of Radburn as a municipality, had it been politically feasible, would probably have been rejected by the planners. ${ }^{32}$ Their intention was to insure their own influence before a heterogeneous collection of home-purchasers had crystallized into a

28 Preface to ULI HANDBOor at $\mathrm{x}$.

29 See text accompanying notes 71-7 infra.

30 Ascher, supra note 24.

31 Id. at 282 .

32 Id. at 279-80. It is not always possible for a New Town to become a municipal corporation. In Radburn's case, the legislative votes were lacking. In the case of Reston, § 15.1-785 of the Code of Virginia stands in the way. That section prohibits unincorporated communities from incorporating as a town or city within the limits of a county, such as Reston's Fairfax County, which has adopted the urban county form of government. Columbia could theoretically incorporate as a municipality, but a long tradition of strong counties has made municipal incorporation a rarity in Maryland. 
community, and then gradually to devolve control upon the residents. ${ }^{33}$ Early directors were appointed by the developers; it was not until 1938, a decade after the Radburn Association was organized, that the majority of trustees were homeowners. ${ }^{34}$

Clarence Stein later criticized Radburn's governmental arrangement:

The Radburn Association was to have the power and functions of a municipal government, including taxation. An American government without public representation! Luckily it was well-administered for the good of the Radburn people.... ${ }^{35}$

This paternalism is reflected in Ascher's comment that "[t]he attitude of the trustees seems more like that of the board of directors of a bank toward its depositors than that of a politically responsible board toward its constituents." ${ }^{36}$

\section{Reston and Columbia-A Description}

"By exciting popular interest and building their demonstration New Towns, [developers Robert Simon, Jr. and James Rouse] have helped to make the New Town idea familiar and acceptable to many Americans." ${ }^{37}$ Although it would be a mistake to suppose that Reston and Columbia are typical of all developing New Towns in America, ${ }^{38}$ the publicity they and their developers have received makes them appropriate subjects for scrutiny.

Reston and Columbia are fraternal twins, born in the middle 1960's in the Washington, D.G. area. Each was created by a private developer who desired to prove the workability, including the profitability, of the New Town idea. But Simon ${ }^{39}$ and Rouse do not have identical conceptions of what a New Town should be, and their ideological differences have been emphasized by the different external forces which have affected Reston and Columbia. Both men are determinists. Simon tends to stress the importance of physical environment, and consequently the emphasis at Reston has been on the quality of architectural detail. Rouse, on the other hand, stresses the importance of

33 Id. at 285-6.

34 Id.

35 STELN, supra note 3, at 61 .

36 Ascher, supra note 24, at 307.

37 Gallantay, Architecture, THE Nation, Dec. 26, 1966, at 714, 716.

38 See Kaplan, supra note 9.

39 Simon is no longer running Reston, but the institutions of concern here are his creation. 
social interaction. As a result Columbia may appear dull and suburban in comparison to Reston, but its environmental planning is probably the most advanced in the country.

\section{A. Influence of Pre-Existing Local Government}

The governmental forms adopted in Reston and Columbia have been influenced by the condition of local government in Fairfax County, Virginia, and Howard County, Maryland, at the time the New Towns were being planned.

Fairfax County, with 400,000 residents, operates under the Urban County Executive Form as the result of a 1966 election. But even before this it was an urbanized county, and Simon believed that it could provide Reston with satisfactory zoning and services. ${ }^{40}$ This meant that Reston itself would not have to create all of the amenities of an urban center for its 75,000 residents.

Rouse, in planning Columbia, encountered a different situation. Howard County is rural, with a population of only sixty thousand. Its political leaders were not immediately receptive to the idea of an instant city of 110,000 being created within the county boundaries, nor was the county capable of providing the variety of high quality services Columbia would need. ${ }^{41}$ Rouse, therefore, had to invent a system of government which could service a city in most major ways. ${ }^{42}$

\section{B. Scheme of Government}

Both Reston and Columbia are unincorporated subdivisions, and both depend, though in different degrees, upon county government for zoning and public services. Both New Towns are organized into a dual, or federal, system of homes associations. In each.town the "central" homes association performs significant municipal-type ${ }^{43}$ functions.

40 Eichler \& KAplaN, supra note 15, at 156. This easy relation between county and New Town is typical of California experience, where half of the New Towns are being built.

41 See generally Hoppenfeld, $A$ Sketch of the Planning-Building Process for Columbia, Maryland, 33 J. Am. Inst. Planners 398 (1967).

42 Other large-scale planned communities have responded to their political circumstances in different ways. Some have managed to become annexed to existing cities. Others have developed close ties with county government. Some have created special districts or "county service areas." See Scott, supra note 15, at 254-5.

43 "Municipal-type" functions is used in an effort to avoid begging the question of what constitutes "public," "municipal," or "governmental" functions. For an example of the confusion inherent in determining what functions are inherently governmental, compare the following tax cases: Allen v. Regents of the Univ. System, 304 U.S. 439 (1938) (university athletic contest); Brush v. Commissioner, 300 U.S. 352 (1937) (water works); Helvering v. Powers, 293 U.S. 214 (1934) (elevated railroad); South Carolina v. United States, 199 U.S. 437 (1905) (liquor dispensary). 
The "peripheral" associations resemble the more traditional homes associations of small subdivisions.

In Reston the central association is called the Home Owners Association. In fact, there are two of these, one located on each side of the Dulles Airport Access Road which bifurcates the New Town. The city will consist of seven villages, each with its own identity. Each village will consist of several small clusters of a hundred or so homes organized as Cluster Associations.

The central organization in Columbia is the Columbia Association. As in Reston, Columbia's constituent villages include ten thousand to fifteen thousand residents. But the peripheral units of organization in Columbia, called Community Associations, serve entire villages, rather than small clusters of homes. The Community Associations are not only much larger than Reston's Cluster Associations, but they carry on more activities.

\section{The Central Homes Association and its Functions}

1. Reston. The corporate purposes of a Reston Homes Owners Association are

(1) to operate and maintain such property as [may be designated or conveyed to it by the developer] to be operated and maintained by the Corporation as parks, parking areas, open spaces, streets, paths, or as other facilities, to enforce the covenants, restrictions, reservations, servitudes, profits, licenses, conditions, agreements, easements, and liens provided in the Deed to be enforced by the Corporation, and to assess, collect, and disburse the charges created under the Deed.... [and] (2) to do any and all lawful things and acts that the Corporation, from time to time, in its discretion, may deem to be for the benefit of the property subject to the Deed and the owners and inhabitants thereof or advisable, proper, or convenient for the promotion of the peace, health, comfort, safety, or general welfare of the owners and inhabitants thereof.44

The articles of incorporation vest the management of the corporation's affairs in nine directors. The initial directors serve five years "and until their respective successors are elected." 45 The first election of directors by the members of the corporation is to be held this year. All elected directors will serve three year terms.

Among the directors' powers are the fixing and collecting of annual dues. These are limited to a maximum of one per cent of any property's

44 Articles of Incorporation of Reston First Home Owners Association, § (b).

$45 I d$., \& (d). 
assessed valuation. ${ }^{46}$ The directors also annually elect the officers of the Home Owners Association. The president is akin to a city manager, ${ }^{47}$ albeit a city manager with a somewhat limited portfolio. $\mathrm{He}$ appoints advisory committees on specific fields of interest, such as planning and budgeting, rules, regulations and enforcement, recreation, and camping.

The members of a Home Owners Association in Reston include the developer, the owner of any lot, and

all persons residing on any portion of the Property who are stockholders, members, or beneficiaries of or otherwise beneficially interested in, a corporation, association, trust, condominium, or other entity owning a portion of the Property and organized and operated for the purpose of leasing or otherwise making residences on the Property ... available to [its stockholders, members, or beneficiaries]. ${ }^{48}$

This excludes mere lessees. The developer excepted, voting is a function of property ownership. In fact, "Any person owning a multifamily dwelling shall have the number of votes equal to the number of apartments contained in such multi-family dwelling." 49 If a unit is held in joint tenancy or tenancy-in-common, the vote must be exercised by unanimous action or consent of the owners of record. Moreover, each voter must reside on the portion of property with respect to which he is entitled to vote. ${ }^{50} \mathrm{By}$ a formula for weighted voting, the developer retains a minimum of one-third of the votes until 1985. ${ }^{51}$

The members of the Corporation

shall have the right to vote for the election and removal of directors and upon such other matters with respect to which a vote of members is required under the Deed or under the provisions of [the non-stock corporation title of the Code of Virginia]. ${ }^{52}$

46 Deed of Dedication, May 3, 1966, recorded in Clerk's Office of Fairfax Co., Va., in Deed Book 2761, page 415, as Instrument No. 12582, II(8).

47 Compare Letter from A. Jackson Lynn, Jr., Public Relations, Gulf-Reston, Inc., Sept. 30, 1968 to author:

Reston's Cluster and Home Owners Associations are not meant to be governmental bodies. The Associations are basically mutual maintenance groups. Granted, some of the functions the Associations perform might be relegated to a "Department of Parks" in a small city, but the head of the Home Owners Association would be more nearly akin to a city manager than a mayor.

48 Articles of Incorporation, supra note 44 , § (c)(2)(C).

$49 I d ., \S(\mathrm{c})(3)(\mathrm{A})$.

$50 I d ., \S(c)(3)(C)$. This provision appears to be in conflict with the provision cited in the previous footnote.

51 Id., § (c)(3)(D).

52 Id., § (c)(3). 
The covenants of the deed of dedication are deemed to run with the land. They are enforceable by the Association, the developer, or by any record owner, in actions at law or suits in equity. Upon the violation of any covenant or restriction, the Association (or the developer or both)

may seek an order from a court of competent jurisdiction permitting it to enter upon the portion of the Property upon or as to which such violation exists, and summarily to abate or remove the same, using such force as may be reasonably necessary, at the expense of the owner thereof. . . . Each purchaser.... agrees that he shall be personally responsible for the payment of all charges that may become liens against his property.....53

The covenants and restrictions continue in force until the year 2005, and then continue automatically for periods of twenty years, unless not less than five years prior to 2005 or any other expiration date, an amendment or vacation of the restrictions and covenants is executed by the holders of more than fifty per cent of the votes of the Association. ${ }^{54}$

The covenants are difficult to amend. With respect to certain basic sections of the deed of dedication, an amendment must have the support of ninety per cent of the votes. Other amendments require either the support of eighty per cent of the votes or, alternatively, fifty per cent of the votes and the approval of at least seven-ninths of the entire board of directors. ${ }^{55}$

In summary, the Reston Home Owners Association is a private corporation operating through an elected board of directors, with powers to hold and maintain property, to enforce covenants and restrictions, and to act affirmatively to provide certain local municipal-type services which could extend to "any and all lawful things and acts . . . convenient for the promotion of the peace, health, comfort, safety, or general welfare of the owners and inhabitants." 56 The corporation has, in effect, a taxing power, enforceable in the courts. Although many of the activities of the Association will touch the daily lives of all the residents, the right to vote for directors is allocated only on the dual bases of property ownership and residency.

2. Columbia. Columbia's planning process is distinguished by its utilization of "work groups" of social scientists who supposedly brought

53 Deed of Dedication, supra note 46, IV(1-3). See Noremac Inc. v. Centre Fill Court, Inc., 164 Va. 151, 178 S.E. 877 (1935).

54 Deed of Dedication, supra note 46 , IV(2-3).

55 Id., IV(5).

56 Articles of Incorporation, supra note 44. 
to Columbia the latest and best thinking on nearly every aspect of community life. Social planners decided that "government" in a new community should consist of many different entities, some private, some public, some quasi-public. ${ }^{57}$ Howard County is expected to provide police and fire departments, water, sewers, schools, snow removal, zoning, and other services, while the Columbia Association-which Rouse considers "a potentially important experiment in its own right"58_provides all municipal services not offered by the county. The Association is empowered to undertake the financing, construction, maintenance, and operation of roads, walkways, parks, libraries, community service facilities, mass transportation, and energy distribution systems. ${ }^{59}$

A Columbia Association brochure states:

It was recognized early in Columbia's planning that the new city would need services and amenities beyond those normally provided by the existing government. . . . The Columbia Association is the mechanism that was developed to afford to the residents a voice in the affairs of the city, and to provide the care, upkeep and operation of all those extras that make Columbia a better place in which to live, work, do business, or raise a family. ${ }^{60}$

The individual property owner as such is not a member of the Columbia Association. The only members, technically, are the directors, who are nominated (and in effect chosen) by a unit called the Columbia Council, whose members are elected for the sole purpose of nominating directors. ${ }^{61}$ Like a city council, the directors appoint a manager to administer and run Association activities.

Each property owner or tenant is automatically a member of a village-level Community Association, and one of his rights is to vote for a village representative to the Columbia Council. Unlike Reston, the vote is allocated primarily by tenancy, since both tenants and owners may vote. The principle of "one unit-one vote," rather than

57 EICHLER \& KAPLAN, supra note 15, at 66.

58 The Messianic Master Builder, LIFE, Feb. 24, 1967, at 40.

59 Erchler \& KAplan, supra note 15, at 75-6. Columbia's Deed, Agreement, and Declaration (recorded in the Land Records of Howard Co., Md., Liber 463, page 158) includes a half-page of small print containing an enumeration of the projects, services, facilities, studies, programs, systems, and properties for which the Columbia Association may expend funds. Random examples include drainage systems, airports, zoos, hospita's, communications systems, and facilities for the fighting and preventing of fires.

60 The Columbia Associatron Today (pamphlet, 1968).

61 See text at note 73 , infra. 
"ownership of one unit-one vote," controls. ${ }^{62}$ As in Reston, jointlyheld property yields but one unanimous vote.

The process of electing directors is complex. Each year the villages elect representatives to the Columbia Council. The Council then nominates from its membership a slate of candidates from which the present directors must elect one new director for each four thousand dwelling units in the city. If the Council only nominates one candidate for each open position, the board must elect the nominated candidates.

In most other respects, the Columbia Association is like the Reston Home Owners Association. The annual charge set by the directors cannot exceed 75 cents per one hundred dollars assessed valuation, ${ }^{63}$ a lower limitation than in Reston. The restrictions run in perpetuity, but after the year 2065, the maximum annual charge may be amended downward to the "amount found by the Board to be necessary to produce sufficient revenue to operate, maintain, renew, replace and repair ... such facilities ... as may be in existence on December 31, 2065. . . ." It would appear, therefore, that Columbia's organization is not only permanent, but programmed for stagnation a hundred years hence.

\section{The Peripheral Homes Associations and Their Functions}

The Reston Cluster Associations are merely smaller homes associations. They function to maintain the parks, pathways, parking areas, and driveways closely related to and serving the one hundred to two hundred housing units in a cluster, acting independently of the Home Owners Association in regard to the small parcels of property they hold. The Cluster Association has a taxing power, presently charging dues of one hundred to two hundred dollars a year. It is managed by a five-man board of directors, the members of which are elected for staggered three-year terms. ${ }^{65}$

While the Reston peripheral association is only the reflection of the architects' grouping of houses, and is probably too small a unit to engender a meaningful political life, the Columbia village association, catering to ten thousand to fifteen thousand residents, is an integral part of Rouse's effort to return human scale to community life. ${ }^{66}$ The

62 Harper's Choice Village Covenants, recorded in the Land Records of Howard Co., Md., Liber 481, page 514, art. III, \$ $3.02(B)$.

63 Deed, supra note 59, art. II, § 2.01 .

64 Id., art. VI, § 6.01 .

65 Prior to 1968, the directors were selected by the developer.

66 Rouse, A Garden for People to Grow In, Trtze NEws, Jan. 1966, at 88, 95. 
powers of the village association, however, are not broad; in fact, the dues at this level are merely voluntary and cannot be enforced. ${ }^{67}$

All owners and tenants automatically become members of their local village association. As members they elect a board of directors which manages the association's affairs. The village association uses the dues and assessments primarily to maintain and improve the common property that has been deeded to it by the developer and the Columbia Association.

The limited functions and economic resources of the cluster and village associations indicate that, whatever the intentions of their planners, they will probably constitute far less significant vehicles for resident involvement in community affairs than their larger counterparts, the central homes associations.

\section{E. Architectural Controls}

Historically, the prime reason for creating a homes association has been to preserve property values by assuring a high standard of architecture and maintenance. Both Reston and Columbia provide for committees with the power to enforce covenants pertaining to the use of privately owned land. Each has covenants that specify what an owner may not do with his property, ${ }^{68}$ and under what circumstances he must receive approval from the architectural committee before making changes. When the owner fails to live up to his obligations, the committee may act for him, charging him for reasonable expenses.

In Reston, there are three Architectural Review Boards, one for each of the Home Owners Associations and a third for Reston's industrial area. The typical Board consists of six architects and two lay members. After 1965,

members of the Board shall be appointed for terms of one year, or until their successors are appointed, one architect and one lay member to be appointed by the [Home Owners] Association and the remaining members by the Developer of Reston. ${ }^{69}$

In Columbia each village Architectural Committee is composed of

\footnotetext{
67 Harper's Choice Village Covenants, supra note 62, art. IV:

The sole remedy for nonpayment of . . . dues and assessments shall be the suspension of the delinquent member's voting rights (except with respect to the casting of a vote for a representative to the Columbia Council) and the right to use Association Land until such payment is made . . . .

68 For example, in Reston there are restrictions against air and water pollution, exposure of laundry to public view, construction of unsightly fences, and use of gas-powered motor boats or boats over eighteen feet long on Reston's waters.

69 Deed of Dedication, supra note 46, I(2).
} 
threè or more individuals àpópintè by both the Columbiã Association and the individual village association, with the Columbia Association always being entitled to âppoint the majority. ${ }^{7 \theta}$

\section{F. The Withering Away of the Developer}

One of the most difficult problems for the community builder is to maintain a balance between his own tieed for control over the developing New Town and the desirability of active participation in the community by its new residents.

Naturally, the developer wants to retain enough power so that he may protect his interests and complete the project according to plan. Additionally, he knows that success or failure in the undertaking (which usually involves an investment of more than fifty million dollars) is dependent upon the viability of the project as a living community; if he limits his own role to physical construction, uncontrolled social and political disintegration may make even the nicest homes unsaleable. On the other hand, the developer is aware that he will eventually desire to withdraw from the project in order to get on with other work, and it is in his interest to leave behind him a strong social and political structure that will advertise his success as a community builder. $\mathrm{He}$ is aware, moreover, that if he is too paternalistic, the residents will become alienated and the development will suffer. Finally, the developer is (or should be) aware that there is a psychological tendency for new residents to be open to new behavior modes for only a short time, perhaps no more than two or three years. If their natural interest in their neighborhood is not harnessed during this early period, it may never be.71 For these reasons, the Urban Land Institute's Homes Association Handbook warns the developer that the early establishment of membership responsibility is essential. ${ }^{22}$

The homes association is an intelligent mechanism for the gradual transfer of power from the developer to the residents of a new community. By establishing the association himself, the developer is able to retain extra voting power during the early stages of development. By appointing the initial board of directors and officers, he can control the early life of the association. As their number increases, the residents can be given greater responsibilities and, through the increasing weight of their vote, exercise a larger amount of power. To assure present and potential property owners of their eventual control, the developer is wise to covenant a date for his own withering away.

\footnotetext{
70 Harper's Choice Village Covenants, supra note 62 , art. VII.

71 ULI HANDBOOK at 244.

72 Id. at $233,241,244$. Sèe id. àt 347 för süğgestéd contróóls àgáîist àbuse of weighted voting.
} 
As a matter of tactics, the developer should express his intention to retain early control and should specify the mechanism which will guarantee his eventual withdrawal. A Columbia Association brochure sets forth Rouse's intentions so that all residents will understand what is happening. ${ }^{33}$ The timetable looks like this:

1966-76-control of the Board by the developer's representatives.

1976-80-offices of original directors expire in annual stages. 1980 - only elected directors remain.

It is not so clear that Restonians will ever take over from their developer. Milton Viorst has written: ${ }^{74}$

To be sure, paternalism exists. .. . Legally, Reston is an unincorporated subdivision of Fairfax County, under the jurisdiction of the county board of supervisors. In reality, it is run by Reston, Va., Inc., Simon's personal corporation. Simon invented "cluster associations," to which the residents of the individual clusters belong, but their sovereignty is limited to common property-walkways and grounds-which they are contractually required to keep clean and in good repair. Simon points out that there is indirect democracy inasmuch as Reston votes for county supervisors. The supervisors, in consultation with Simon, build the schools, provide police and fire protection and make available other necessary services. But in approving Simon's master plan, the supervisors all but abdicated to him the prerogatives of government that will determine Reston's fate. . . . It is conceivable-though by no means likely-that the residents could some day wrest control from Simon's corporation through a device called the Home Owners Association. But for now, the Association serves as a semi-democratic facade behind which Simon exercises power. For all practical purposes, there is no democracy at Reston; the community is Simon's fief.

However accurate this description, it appears that Viorst is misstating the issue. If the nation is committed to the building of New Towns by private developers free of regulation, it seems unavoidable that we accept a developmental period during which a "semi-democratic facade" prevails. Indeed, the planning and construction of a $\mathrm{New}$ Town is such an expensive, complicated process that there may be no feasible way to combine a developmental period with meaningful resident participation. The appropriate question, therefore, is not

73 The Columbia Association TOday, supra note 60, at 15.

74 Viorst, Reston, supra note 20 , at 39. 
whether democracy exists in the infant Reston, but whether it will exist before too many years. For the short run, a rough kind of democracy of the market place exists-the resident selects his leader by choosing to settle in the developer's new community. For the long run, it is essential to ask whether there are built-in protections against the developer's prolonging his term of office beyond its economic justification.

This question becomes even more important as it pertains to Reston, because Robert Simon, an individual devoted to what he perceived to be the New Town ideal, has been replaced by Gulf Oil, a corporation whose spokesman says that a developer should "listen to the market"75 rather than to the city planners and architects. Unless the market (or government) requires some protections for democracy, the residents of Reston will be dependent only on the protections of their covenantsand these do not clearly define any policy of developer withdrawal. The developer's weighted voting power, for example, continues in effect for a long period, giving him a minimum of one-third of the votes in the Home Owners Association until the time when his property holdings alone would give him only one-fifth of the votes; and until 1985 the developer is absolutely guaranteed one-third of the votes, even if all the lots are sold and housing units occupied. ${ }^{76}$ The Architectural Review Boards remain in the developer's control indefinitely. ${ }^{77}$ Gulf Oil already has a monopoly in Reston for some of its products, such as gasoline; it does not stretch the imagination to see Gulf maintaining a permanent hand in the governing of Reston.

\section{The Homes Association IN the New Town Context}

The employment of the homes association idea in the context of a New Town constitutes a break with the past. If, as some have argued, New Towns are merely large subdivisions, few subdivisions have been so large. ${ }^{78}$ Nor have there been many examples of planned unit development ${ }^{79}$ which have presented the coherent, distinct, and balanced character of a New Town. The homes association was developed in small, homogeneous, wealthy surroundings. Only three per cent of all existing developments with homes associations have more than five

75 Von Eckardt, Are We Being En-Gulfed? NEw REPUBLuc, Dec. 9, 1967, at 21, 23.

76 Deed of Dedication, supra note $46, \mathrm{II}(7)(\mathrm{b})$.

77 Id., I(2).

78 Even Radburn, which was planned for 25,000 residents, but was truncated by the Depression, served only about 650 families.

70 Urban Land Institute, Technical BurL. No. 40, New approaches to Residential Land Development (1961). 
thousand homesites. ${ }^{80}$ Approximately 75 per cent are in the high or medium-high price range. ${ }^{11}$ And it can be assumed from a cursory look at today's suburbs that most of these subdivision developments are racially and ethnically homogeneous.

But the New Town will not be small, homogeneous, or even predominately wealthy, according to existing planns. Reston will have a population of over seventy thousand; Columbia will have 110,000. The New Town at the Irvine Ranch in California will be home for 500,000 people. ${ }^{82}$ Where the average homes association serves a deyelopment of between tẹn and one thousand acres, ${ }^{83}$ Reston will have over one thousand açes of park and public land alone. Columbia will cover fourteen thousand acress. ${ }^{84}$ As to wealth, both Rouse and Simon have expressed the ideal of a mixed populace. Rouse intends that ten per cent of Columbia's housing will be available to families with under $\$ 4000$ a year income. ${ }^{85}$ Negroes and other minority groups will be welcome in each community. A black director has already been elected to the board in Columbia. Finally, the New Towns will be heterogeneous in terms of land use, especially in comparison with the typical suburban subdivision in which the homes asseciation has been used.

The most compelling distinction between the usual homes association and the Reston-Columbia homes association can be seen in terms of function. Historically, the homes association has administered covenants for architectural harmony and permanent upkeep of the neighborhood. The peripheral homes assaciations in Reston and Columbia are in this tradition. But on the central level in Reston, and even more so in Columbia, the homes association not only preserves property values, but also allocates tax funds and provides municipal-type serviçes. It is difficult to read the following annual report of the Rouse Company, for the year ending May 31, 1968, without concluding that the Columbia Association is more like a municipal government than a private corporation:

During the year, the Association brought into operation the bus system, two golf courses, four swimming pools, a tennis

\footnotetext{
80 ULI HANDBOOK at 19.

81 Id.

82 New Town Rises Back at the Ranch, Bus. WeEx, Sept. 23, 1967, at 176.

83 ULI HANDBOoK at 19.

84 Volpert, Creation and Maintenance of Open Spaces in Subdivisions: Another Approach, 12 U.C.L.A.L. REv. 830, 835 (1965), points out that the practical problems of a homes association become "acute" when the development covers a large area and includes a planned community containing many different land uses.

85 Rouse plans for a wide range of income levels within a village, but does not intend to foster economic integration within the small clusters that constitute the village. Hearings, supra note 15 , at 983.
} 
club, a child-care center, a teen-agers' club, two community buildings, more than 200 acres of parks, bọating, fishing, and skating on two lakes and a wide range of other facilities and activities. The Association received a grant of $\$ 277,000$ from the Department of Housing and Urban Development to explore new systems of public transịt for Columbịa and for a study and demonstration of minibus operations as a means of public transportation.

It is still too early to predict whether Reston and Columbia have created forms of local government which will give residents a sense of community and personal control over environment. A judgment as to the success of these New Towns in creating a contemporary reality for the "republic in miniature" ideal ${ }^{86}$ will have to wait at least until the 1980's, when the developmental period will have ended. But, on the basis of what has been written to date, one would gather that Reston will not be promoting any kind of "participatory democracy." The Home Owners Association is tog much under the control of the developer and too limited in its contemplated activities to be a locus of active self-government. Moreover, the division of Reston into two Home Owners Associations deprives the New Town of political integrity. Columbia's potential is more reassuring. Columbia has a single Association that will carry on enough activities to capture the interest of the residents, and the residents are guaranteed eventual control over it. The village associations, in addition, reflect a human scale of community and may turn out to be a viable way to organize a larger community into functional divisions. As a test tube for the idea of decentralization, the Columbia experiment should be watched carefully.

As a mechanism to "afford to the residents a voice in the affairs of the city,"87 however, even the Columbia Association is open to criticism. The limitation of the franchise to property owners and tenants-especially after the development period-may well be at variance with democratic theory in this country, as embodied in recent decisions of the Supreme Court. Whether or not New Towns are subject to constitutional requirements, the establishment of voting arrangements within them which disregard these requirements casts a serious shadow over the integrity of the governmental process in these communities. ${ }^{88}$

86 The phrase is from R. Wood, Suburbia 18 (1956). There is some evidence that the "neighborhood unit" theories for new communities have not generated significant community life in the British New Towns. Willmott, Social Research and New Communities, 33 J. Am. Inst. of Planners 387 (Nov. 1967).

87 See text accompanying note 60 supra.

88 The problem raised here is not academic. In fact, there are indications that 
"One unit-one vote" in the home owners' associations disfranchises those who do not own property or (in Columbia) rent it. This voteless class of residents could include young adults living with their parents, spouses who do not hold jointly, older people sharing their children's home, and perhaps others. And, because of the unanimous consent rule for jointly-owned property, co-owners or co-tenants who cannot agree on how to vote are also disfranchised. Finally, in Reston owners of more than one dwelling unit may be permitted to cast more than one vote, thereby diluting the weight of other individuals' single votes.

\section{A. Equal Protection Requirements for Voting in Municipalities}

If a public municipal government instead of a homes association had voting qualifications like those in Reston and Columbia, it would be subject to two lines of constitutional attack. First, property-either ownership or tenancy-as a prerequisite for voting may be constitutionally invalid. Second, "one unit-one vote" favors the small household as against the large, in contravention of the standard established in the reapportionment cases.

In Harper $v$. Virginia Board of Elections in 1966,89 the Supreme Court held that a poll tax is invalid because of its inconsistency with the equal protection clause. Building on Gray $v$. Sanders, ${ }^{90}$ a reapportionment case, Justice Douglas noted that "neither homesite nor occupation affords a permissible basis for distinguishing between qualified voters within the State." He added, "We think the same must be true of requirements of wealth or affluence or payment of a fee." 91

This decision has been interpreted by a three-judge federal district court to imply that a statute which bars otherwise qualified voters from voting on a proposed change in village government because they do not own assessed property in the village violates the equal protection clause.92 "Whether that change should be made affects all who live in the Village so that denying the franchise to those who do not own real property is an invidious discrimination."

In another case, Landes $v$. Town of North Hempstead, ${ }^{94}$ the New York Court of Appeals held that a town law which required a holder

Columbia residents, at least on the village level, are beginning to push for a "one man -one vote" scheme. Columbia, Maryland, Times, Nov. 28, 1968 at 1.

89383 U.S. 663 (1966).

90372 U.S. 368 (1963).

91383 U.S. at 667.

92 Pierce v. Village of Ossining, 292 F. Supp. 113 (S.D.N.Y. 1968).

93 Id. at 115 .

94 Landes v. Town of North Hempstead, 20 N.Y.2d 417, 231 N.E.2d 120, 284 N.Y.S.2d 441 (1967). 
of elective office to be an owner of record of real property within the town violated the equal protection clause. Chief Judge Fuld wrote:

In a society such as ours, characterized by its "mobility" and "anonymity" . . . a landowner is no more likely to be permanently established in a town-and, by that token, better qualified to govern-than one who is not a property owner. ... We suggest that it is impossible today to find any rational connection between qualifications for administering town affairs and ownership of real property. ${ }^{95}$

The opinion deals with office holders, but its reasoning could apply equally to voters in local elections. It rests upon a finding that property ownership is not a rational criterion for public participation. Two district courts have taken a different view, however, distinguishing elections for general governing bodies from narrower kinds of elections.

In Kramer v. Union Free School District No. $150^{90}$ a 28 year-old bachelor residing with his parents in their private home was not allowed to register to vote in a school district election, because the Education Law of New York requires voters in such elections to be property owners, lessees, or parents with school-age children. Kramer argued that the statute resulted in discrimination based on property, or wealth, violating the fourteenth amendment as interpreted in Harper and Landes. A three-judge district court held, two to one, that the equal protection clause did not apply. The school district election is " a local election on limited issues as to which certain local residents have a far greater direct interest than others." 97 This, the court said, was an important difference from Harper and Landes, in which the elections concerned general governing bodies whose decisions directly affect all residents. It is not unreasonable for the legislature to determine that the local school system should be run by those who have a direct interest in it-those who have to pay for it and those who benefit from its services. On the other hand, Judge Weinstein's dissent demonstrated in detail that every resident has a direct interest in the educational system of the community, and that to exclude a citizen from participation in this locus of government is to deprive him to a significant degree of control over the total government of the nation..$^{98}$ Judge Weinstein also suggested that the court erred in its belief that

9520 N.Y.2d at 420,231 N.E.2d at 122, 284 N.Y.S.2d at 444.

96282 F. Supp. 70 (E.D.N.Y.), cert. granted, 393 U.S. 818 (1968).

87 Id. at 74 .

$88 \mathrm{Id}$. at 76. 
a property qualification eàn be placeed on voting, evven if it is reasonable. The Supreme Gêurt grànted certiorari on October 14, 1968.

In Cipriano v. City of Houma, ${ }^{99}$ a three-judge district court in Louisiâna refuisèd to ènjoin the city from išsiung utility reveriue bonds approved by a vote of the prop̃erty taxipayyêris at à special election, holding thăt there wàs no violation of the equal protection clause because the distinction drawn between resident voters who are property owners and resident voters who do not own property is neither arbitrary nor invidious. The court stressed that this was not an election for general purposes, but one which merely concerned the administrative functions of the municipality ${ }^{100}$ Gircuit Judge Wisdom dissented, pointing out that in both Harper and Cipriano the eligibility to vote rested on payment of a tax. ${ }^{101}$ Although he agreed that the question was whether the distinction between property and nön-property owners is rational, his conclusision was that Harper required a negative answer.

To summarize, undoubtedly a property qualification for the vote will not be upheld in an election for a general governing body: It is also likely thát sùch a qualification would fáil in an election where the outcome would affect all residents in a significănt way; even if some residents wờild be affected more directly than others. However, "significant" has not yet been given clear meaning by the Supreme Court. Its decisions in Kramer and Gipriano should throw light on that problem. Whether a property qualification can be justified simply because it can be shown to be reasonable is another problem the Court miay decide. On the basis of Harper, it would appear that the rational= ity of a property qualification is not at issue and that the real problem is to set guidelines for determining when a public decision-making body exercises power in such a way that all residents are affected directly enough that exclusion from participation is an invidious dis= crimination.

Thus far, the discussion has emphasized that "one unit-one vote" is wrong. Another approach to the problem would stress that "one man-one vote" is right.

The reapportionment princièple was applied to muniçipal gơvèrnmients in the 1968 case of Avery $y_{:}$Midland County ${ }^{102}$ Justice White wrote:

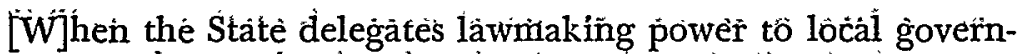
mènt and providés for the electión ơf lócal officials from dis=

99286 F. Supp. 823 (E.D. La: 1968).

100 See discussion of Aìery athd Sailors cases in text infra.

101286 F. Supp. at 828.

102390 U.S. 474 (1968). 
tricts specified by statute, ordinance, or local charter, it must insure that those qualified to vote have the right to an equally effective voice in the election process. ${ }^{103}, \ldots$ We hold today only that the Constitution permits ne substantial variation from equal population in drawing districts for units of local government having general governmental powers oyer the entire geographic area served by the body. ${ }^{104}$

The Court stressed that the county government in question was a unit with general governmental powers and noted that it was typical of county, town, and village governments across the nation. This distinguished the case from Sailors $v$. Board of Education, ${ }^{105}$ decided in 1967, where it was held that since no election was required for members of a county board of education which performed essentially administrative functions, the principle of one man-one vote did not apply, even though members were selected on the basis of one vote for each local school board, regardless of population. The Court said that this arrangement resulted in county board members being appointed, rather than elected, and no question of reapportionment was presented. The later school board and revenue bond cases differ in that elections were held.

Although Avery, like the other reapportionment cases, speaks to the problem of unequal voting districts, the same considerations would apply to individual voters whose votes have unequal weight. When districts are unequal, it is the individual citizen's vote which is diluted and debased, and he is the one, in the final analysis, who is guaranteed equal protection of the laws. ${ }^{108}$

The equal protection cases in the Supreme Court seem to indicate that the judiciary should make an independent examination of the reasonableness of a legislative classification which denies a group the right to vote. ${ }^{107}$ In this examination, it appears that no factor other than unfitness to vote is a reasonable bar to voting rights. ${ }^{108}$ That un-

103 Id. at 480 .

$104 I d$. at $484-5$.

105387 U.S. 105 (1967).

100 Reynolds v. Sims, 377 U.S. 533 (1964).

107 Kramer v. Union Free School Dist. No. 15, 282 F. Supp. at 75-87 (dissenting opinion). Ses Carrington v. Rash, 380 U.S. 89 (1965). Williams v. Rhodes, 393 U.S. 23 (1968), follows a similar tack as to qualification of candidates for the ballot. This ap proach was followed by the majority in Kramer but not by that in Gipriano, which de. ferred to the wisdom of the legislature in barring non-property taxpayers from the pote. 108 Both fear of the voting patterns of disfranchised servicemen and difficulties of proving residence were rejected as reasonable legislative considerations in Carrington v. Rash, 980 U.S. 89, 93-6 (1965). Similarly, all other considerations in reapportionment were rejected except the "one man-one vote" principle in Reynolds v. Sims, 377 U.S. 553, 581 (1964). 
fitness may be measured only by inability to make a wise voting decision $^{109}$ or by disinterest in the subject matter of the election..$^{110}$

It follows from Harper and Avery that voting arrangements like those adopted for Reston and Columbia would be unconstitutional for a municipal government exercising general governmental, as opposed to purely "administrative," powers. A general municipal government cannot adopt a "one unit-one vote" scheme; it remains to.be seen whether a private homes association is subject to similar constitutional constraints.

\section{B. The Applicability of Equal Protection Requirements to the New Towns}

In its New Town embodiment, the homes association closely resembles a municipal corporation. Like a municipal corporation, the New Town homes associations described here are corporate and perpetual, possess a taxing power, are established primarily to regulate the internal affairs of a geographic area for the benefit of the residents, and are governed by elected bodies. Although lacking eminent domain powers, they do have a kind of zoning power in their architectural committees. Instead of a legislative charter, they operate under articles of incorporation and recorded land agreements that have been approved and are enforced by agencies of the state.

Unlike the municipal corporation, the homes associations are private; membership, at least in theory, is voluntary. Whereas all residents of a municipality are members of the municipal corporation, only residents with a property interest are members of the homes association. The constitutional question, therefore, is whether the similarities of the homes association to a municipal government require the application of constitutional requirements to them, despite their "private" character. ${ }^{111}$

This question has not been litigated. The applicability of the four-

109 Illiteracy, Lassiter v. Northampton Election Bd., 360 U.S. 45 (1959), and conviction for a felony, Green v. Board of Elections, 380 F.2d 445, 451 (2d Cir.), cert. denied, 389 U.S. 1048 (1967), and cases cited therein, have been held reasonable grounds for disfranchisement.

110 Residence is the outstanding example. Pope v. Williams, 193 U.S. 621 (1904). It has also been assumed that the vote in special-purpose districts may be limited to those assessed by the district because of its narrow purpose. Kramer v. Union Free School Dist. No. 15, 282 F. Supp. at 84 (dissent).

111 By barring lessees, the Reston voting scheme denies the vote to a group which pays the property owner's dues in the association as part of its rents. The amount of the dues has a direct impact on lessees to the extent that it is reflected in rents. The lessees -and others excluded from the franchise in both Reston and Columbia-have an interest in the maintenance of sidewalks, social activities, and other functions provided by the home owners associations. 
teenth amendment to private organizations has arisen only in the context of first amendment rights or racial discrimination. The courts have not been faced directly with the question of the constitutionality of the internal structure of a private organization. ${ }^{112}$ But they have been called upon to determine when a "private" area becomes public for first amendment purposes and when a "private" function becomes public for equal protection purposes. These two lines of cases, neither of which is without its problems, may cast some light on the susceptibility of New Town voting arrangements to constitutional attack.

1. The "Public Area" and the First Amendment. In 1946 Chickasaw, Alabama was a company town, wholly owned by the Gulf Shipbuilding Corporation, with "all the characteristics of any other American town." It consisted of "residential buildings, streets, a system of sewers, a sewage disposal plant and a 'business block' on which business places [were] situated." The town and its shopping district were "accessible to and freely used by the public in general and there [was] nothing to distinguish them from any other town and shopping center" except their private ownership. A Jehovah's Witness was prosecuted and convicted under the Alabama trespass law for attempting to distribute literature on a sidewalk of the business block in violation of a company rule against solicitation on its property. In Marsh $v$. Alabama $^{113}$ the Supreme Court reversed the conviction, holding that private ownership is no justification for a state's "permitting a corporation to govern a community of citizens so as to restrict their fundamental liberties and the enforcement of such restraint by the application of a state statute."114

The Court's opinion, by Mr. Justice Black, stressed the importance of first amendment freedoms for residents of company towns. They are, he wrote, "free citizens of their state and country," who, like all other citizens, "must make decisions which affect the welfare of community and nation." To do so, "they must be informed," and, accordingly, "their information must be uncensored." The corporate managers "cannot curtail the liberty of press and religion of these people consistently with the purposes of the Constitutional guarantees"; the application of a state statute to enforce such action by criminal sanctions is unconstitutional. ${ }^{115}$

112 Cf. Steele v. Louisville \& Nashville R.R., 323 U.S. 192 (1944) (Railway Labor Act imposes a duty on a craft union to represent all members of the craft, but does not deny the union the right to determine eligibility for membership), and concurring opinion of Mr. Justice Murphy, at 208-9.

113326 U.S. 501 (1946).

114 Id. at 509 .

$115 I d$. at 508 . 
The Märsh test of ăn area "freely accessible and open to the people in the ärea and those passising through" was recently extended by the Court, in invalidating a státe injunction àgåinst peaceful non-employee picketing of a privately=owned shopping center. ${ }^{\mathbf{1 1 6}}$ The Court held that access tó propeperty "functioning à à business district" for the purpose of exercising first amendmeñit rights "should [not] be limited simply because the property surrounding the 'business district' is not under the same ownership."117 The state "may not delegate the power, through the use of its trespass laws, wholly to exclude those members of the public wishing to exercise their First Amendment rights on the premises in a manner and for a purpose generally consonant with the use to which the property is actually put."118

2. The "Public Function" and Equal Protection. Marsh and the shopping center case dealt with the constitutionality of state court enforcement of restrictions on speech in areas open to the public. But Marsh contains language suggesting that the company itself was subject to fourteenth amendment limitations. Mr. Justice Black stated the issue in the case as follows:

$[I] t$ is clear that had the people of Chickasaw owned all the hơmes, and all the stores, and all the streèts, and all the sidewalkś, all thiósè ownérs together̉ could not have set up a municipal government with sufficient poiwers to pass an ordìnance completely barring the distribution of religious literature: Oür question then nárrows down to this: Can those people who live in or cöme to Ghickảsału be denied freedom of press and religion simply because a single company has legal title to all the town?119

1 iis Ámalgamated Food Emíployees Union v. Ĺgàn Plaza, 391 U.S. 308 (1968).

$117 \mathrm{Id}$. at 319 .

118 Id. at 320. Cf. Watchtower Bible and Tract Society v. Metropolitan Life Ins, Go., 297 N.Y. 339 , 79 N.E. 2 d 433 , cert. denied, 335 U.S. 886 (1948) (No violation of the fourteenth̆ àmendment in preventing Jehovah's Witriesses from distribüting literature "inside of, añd into, thè sêverăl floòrs and inner hallways of multiple dwellings," here a private residential commünity of high-rise apärtments̀ covering 129 acres and housing 35,000 people, with two public highways, private street lanes, and parks, as well as shops, offices and service stations run by tenants); Hall v. State, $18 \dot{8}$ va. 72,49 s.E.2d $36 \hat{9}$, appeal dismisšed, 335 U.S. 875 (1948); rèaching the same conclusion with respect to a single apartment building with sixty units. Mr. Justice Black, dissenting in the shopping center case, would apparently apply a "bird's-eye view" approach to define a "public area," even in the first amendment context:

Under what circumstances can private property be treated as though it were public? The answer that Marsh gives is when that property has takèn on all thè attributés ố à town, i.ë., 'rèsidèntiāl buildińğ', streèts, a sýstem of sewers, a sewage disposal plant, and' a 'business block' on which businéss plä́ces ăre situated ...

I can find nothing in Marsh which indicates that if one of these fèatiures is present ... this is sufficient. . . " 391 U.S. at 332.

119 Marsh v. Alabama, 326 U.S. at 505. 
"Ownership," Mr. Justice Black wrote, "does not always mean absolute dominion. The more an owner, for his advantage, opens up his property for use by the public in general, the more do his rights become circumscribed by the statutory and constitutional rights of those who use it." ${ }^{120}$ Ownership, he argued, is not determinative of constitutional rights:

Whether a corporation or a municipality owns or possesses the town the public in either case has an identical interest in the functioning of the community in such manner that the channels of communication remain free. ... [T] he town of Chickasaw does not function differently from any other town. ${ }^{221}$

Accordingly, constitutional rights are the same as in any other town.

This aspect of Marsh has been further developed in later cases, to suggest a "public function" doctrine of state action for fourteenth amendment purposes. ${ }^{122}$ The doctrine, never clearly articulated in the case law, has two, not totally separable elements-the character of the conduct by private parties and state involvement through delegation, complicity, or inaction. ${ }^{123}$ Both are reflected in the leading case suggesting the doctrine, Evans v: Newton:

Conduct that is formally "private" may become so entwined with governmental policies or so impregnated with a governmental character as to become subject to the constitutional limitations placed upon state action. . . . A town may be privately owned and managed, but that does not necessarily allow the company to treat it as if it were wholly in the private sector. Thus we held in Marsh $v$. Alabama ... that the exercise of constitutionally protected rights on the public streets of a company town could not be denied by the owner. ... We have also held that where a State delegates an aspect of the elective process to private groups, they become subject to the same restraints as the State. Terry $v$. Adams, 345 U.S. 461 . That is to say, when private individuals or groups are endowed by the State with powers or functions governmental in nature, they become agencies or instrumen-

$120 \mathrm{Id}$. at 506 .

$121 \mathrm{Id}$. at $507-8$.

122 "[T] $]$ he action inhibited by the first section of the Fourteenth Amendment is only such action as may fairly be said to be that of the States." Shelley v. Kraemer, 334 U.S. 1,13 (1948).

123 See, e.g., Terry v. Adams, 345 U.S. 461 (1953); Smith v. Allwright, 321 U.S. 649 (1944), holding that voting in Democratic primaries was such an integral part of the electoral process that delegation of state control to the Democratic Party served to make the Party's action that of the state, thereby subjecting it to constitutional requirements. 
talities of the State and subject to its constitutional limitations. ${ }^{124}$

Other statements of the "public function" approach to state action also utilize these two elements, professing to derive them from Marsh. In arguing that the constitution requires that public accommodations be desegregated, Mr. Justice Douglas found support in Marsh, which he read to stand for the proposition that privately-owned towns "perform municipal functions and are held to the same constitutional requirements as ordinary municipalities."125 $\mathrm{Mr}$. Justice Goldberg, making a similar argument, cited Marsh, among other cases, for the principle that "state conduct which might be described as 'inaction' can nevertheless constitute responsible 'state action' within the meaning of the Fourteenth Amendment."126 In dissent in the shopping center case, ${ }^{127} \mathrm{Mr}$. Justice White argued that in Marsh, "the company ran an entire town and the state was deemed to have devolved upon the company the task of carrying out municipal functions"; ${ }^{128}$ the

124382 U.S. 296, 299 (1966). Evans involved the constitutionality of a state court appointment of private parties to replace the city of Macon, Georgia as trustees of a tract of land which had been devised to the city in trust in 1911 for use as a park for white people only. The city had taken the position that it could not maintain the park on a segregated basis. The Court held that the transfer to private trustees was unconstitutional. There were alternate bases for the holding, aside from "public function." For years the park was "an integral part" of the city's activities; the "momentum it acquired as a public facility [was] certainly not dissipated ipso facto by the appointment of "private' trustees." Id. at 301. There was no indication on the record that the city did not continue to maintain the facility; "[i]f the municipality remains entwined in the management or control of the park, it remains subject to the Fourteenth Amendment." Id. Moreover, the state had held that it had equitable power to appoint new trustees to assure that the purpose of the trust-the provision of a park for whites only-did not fail. Id. at 298. See also id. at 302-12 (White, J., concurring).

In dissent, Mr. Justice Harlan argued that the "public function" test lacked any "firm doctrinal support," id. at 321, and had "perverse potentialities" as to "a host of ... functions commonly regarded as nongovernmental though paralleling fields of governmental activity." Id. at 322. On the first point, he found Marsh to be the only "Fourteenth Amendment case finding state action in the 'public function' performed by a technically private institution." Id. at 320. He belittled the significance of the Marsh doctrine, indicating that it "has not since been the basis of other decisions in this Court and certainly it has not been extended." $I d$. at 321 .

125 Garner v. Louisiana, 368 U.S. 157, 181 (1961) (concurring).

126 Bell v. Maryland, 378 U.S. 226, 310-1 (1964). See also Reitman v. Mulkey, 387 U.S. 369, 384 (1967) (Douglas, J. concurring): “Zoning is a state and municipal function. . . . When the state leaves that function to private agencies or institutions which are licensees and which practice racial discrimination and zone our cities into white and black belts or ... ghettoes, it suffers a governmental function to be performed under private auspices in a way the state itself may not act."

127 Amalgamated Food Employees Union v. Logan Plaza, 391 U.S. at 337.

128 Id. at 340 . 
company "stood in the shoes of the state in attempting to prevent the streets from being used as public streets are normally used." 129

The United States, in its amicus brief in Jones v. Alfred H. Mayer Co., ${ }^{130}$ advanced this "public function" argument as grounds for holding that it was unconstitutional for the developer of a private subdivision of about one thousand residents to refuse to sell a lot to a Negro because of his race. The subdivision, Paddock Woods, was planned as a complete suburban community and was controlled by a board of trustees appointed by the developer. The government argued that

respondents, in operating their new community, act in much the same manner as a municipal corporation. They begin by establishing community boundaries, with the review and approval of the State. With State review and approval they establish streets, sewers, and recreational facilities-services the public has come to expect from its municipal governments. They establish rules which the residents of the community must follow and which the State enforces. They appoint a governing body.... They furnish continuing services, such as rubbish collection, and levy assessments-enforceable by judicial process-to pay for the services.... And these acts are done under the supervision of a complex structure of district, county, and State agencies, under the State law. . . . ${ }^{\mathbf{1 3 1}}$

The government suggested analogies between the subdivision's architectural controls and municipal zoning ordinances, and between the subdivision's assessments and public taxes, drawing the conclusion that "those who rule the community, although they wear no uniform and hold no official title, wield those powers to perform essentially governmental functions." 132

The courts have never had to extend the public function doctrine this far. In Jones itself, the Supreme Court avoided the constitutional issue by holding that the discrimination violated a Reconstruction statute Congress had the power to enact under the thirteenth amend-

129 Id. at 337. See also Guillory v. Administration of Tulane Univ., 203 F. Supp. 855, 859 (E.D. La. 1962), where Judge Skelly Wright argued: "Clearly, the administrators of a private college are performing a public function. They do the work of the state, often in the place of the state. Does it not follow that they stand in the state's shoes? And, if so, are they not the agents of the state, subject to the constitutional restraints on governmental action, to the same extent as private persons who govern a company town ... ?"

130392 U.S. 409 (1968).

131 Brief for Plaintiff as Amicus Curiae at 7-8.

132 Id. at 14 . 
ment.133 And the earlier line of sit-in cases, in which "public function" arguments for imposing a constitutional duty not to discriminate on store-owners had been advanced, ended with the passage of the public accommodations provisions of the 1964 Cixil Rights Act.

The Supreme Court in Marsh had to decide whether a private town was the equivalent of a public town for first amendment purposes. It decided that it was, and the opinion in that case has led to two doctrines, both of which have been extended well beyond private towns. One deals with the nature of areas open to the public; while geographically oriented, it is of little relevance to the question of whether a New Town must be organized with a democratic form of government. The other, which has never served as the sole basis of a Supreme Court holding, deals with functions; while ostensibly concerned with whether an activity is governmental in character, it has not been utilized to suggest that the internal structure of the organization administering the function must meet constitutional standards, but only that the function must be administered in a non-discriminatory manner. .34

"Other rights, even the most basic, are illusory if the right to vote is undermined," the Supreme Court has said.135 Indeed, in Marsh the Court was concerned about maintaining a free flow of information to citizens of company towns so that they could properly exercise their responsibilities to "make decisions which affect the welfare of community and nation," even though they did not elect the company officials who ran their town.

If can be argued from the primacy of the right to vote, and the combination of the Marsh and Evans doctrines, that New Towns should be subject to equal protection standards in allocating the

133392 U.S. 409 (1968). On this case, see Casper, Jones ע. Mayer: Clio, Ganfused and Bemused Muse, 1968 S. CT, REv: 89.

134. Marsh also suggests a third doctrine-the public interest in the functioning of the private entity. In Marsh, the Court said, "Whether a corporation or a municipality owns or possesses the town, the public in either case has an identical interest in the functioning of the community. . . " 326 U.S. at 5097 (italics added); (Ṭhe full sentence is quoted above in the text accompanying note 121.) This implies an equal protection analogue of the doctrine of property "affected with a public interest," the due process test for the constitutionality of state regulation of a business. Ghief Justice Waite stated the test in Munn v. Hlinois, 94 U.S. 11 , 126 (1876), as follows: "Property does become clothed with a public interest when used in a manner to make it of public consequence, and affect the community at large." In their sit-in opinions, Justices Đouglas and Goldberg urged the application of this doctrine in the equal protection area. See Bell v. Maryland, 378 U.S. 226, 312-5 (1964) (concurring opinion); Lombard v. Louisiana, 373 U.S. 267, 274-8 (1963) (concurring opinion). See also Reitman v. Mulkey, 387 U.S. 369, 385.6. (1967) (concurring opinion).

135 Wesberry v. Sanders, 376 U.S. 1, 17 (1964). 
franchise. Like Chickasaw, New Towns have "all the characteristics of any other American town"; like the park in Macon, "the predominant character and purpose" of the homes associations in New Towns "are municipal."."136 If this argument is accepted and if, as suggested above, "one unit-one vote" is constitutionally impermissible, then the covenanted voting arrangements might be judicially overturned and the franchise opened to all residents..$^{137}$

It is not difficult to imagine circumstances under which a case could arise that would bring the New Town voting arrangements into the courts. Perhaps the excluded residents would find themselves directly affected by an approaching homes association election and would seek an injunction against the enforcement of the property requirements and a decree that all otherwise qualified voters be permitted to vote on the principle of one man-one vote. ${ }^{138}$ Such an order would have the effect of setting aside only the clauses of the land agreements and articles of incorporation which pertain to who can vote in a central

126 This is not to suggest that a New Town must have an elected government, but only that if it does, the "one unit-one vote" standard may be impermissible. To paraphrase Avery, when there is a provision for election of local officials, those qualified to vote have the right to an equally effective voice in the election process. See text accompanying note 102 supra.

Moreover, not all homes associations (in New Towns or other communities) should necessarily be required to open the franchise to all residents merely because they perform some "public function." "Private governments" should be distinguished from private entities performing a single public function, and New Town associations like those described in this comment from limited-purpose subdivision homes associations. $C f$. Avery v. Midland County, 390 U.S. 474 (1968); Pierce v. Village of Ossining, 292 F. Supp. 113 (S.D.N.Y. 1968); Kramer v. Union Free School District No. 15, 282 F. Supp. 70 (E.D.N.Y.), cert. granted, 393 U.S. 818 (1968). Among the criteria that are relevant in making this distinction are the extent of the municipal-type services performed by the association, the size (both in population and area) of the community it services, and the importance of the services to residents excluded from the franchise. Finally, it may be useful to apply the gestalt approach suggested by Marsh. Does the community served by the association look like a town? A definition like that quoted in note 6 supra may be usefully applied in answering the question.

137 There are, of course, other methods of organizing the "political" structure of the New Towns. In California, for instance, the establishment of special districts by developers has been widely favored. Under this procedure, owner control is assured for a period of time because two of the three directors of such a district are elected by property owners on the basis of the assessed value of their holdings. Because this type of government may lead to conflict between the developer and the residents, measures have been initiated to stem abuses by the developers. For example, local agency boundary commissions, representing counties, cities within the county, and the public now play a positive role in the development of appropriate governmental organization for urban areas. See ACIR 91-3.

138 In Pierce v. Village of Ossining, 292 F. Supp. 119 (S.D.N.Y. 1968), the district court enjoined the operation of a statutory property requirement so that all who wished to vote in the scheduled election could do so. 
homes association election. These clauses are severable, ${ }^{139}$ and their invalidation would not upset the entire covenant structure.

It is conceivable that a court would not stop with the voting arrangement but would import the entire Constitution into its decision, invalidating the requirement that office holders be members of the association and looking into such other problems as due process, impeachment, and amendments. Moreover, it is possible that a court could decide that the private government is a sham municipal corporation, and in violation of state law in regard to municipal corporations. At this early date, however, when there is almost no knowledge of how the New Towns will actually operate politically, such a decision would be unfortunate and unnecessary. Instead of finding that these private governments are in fact municipal corporations, it should be sufficient to say that they resemble municipal corporations. This distinction would permit a case-by-case determination of how far policy requires incorporation of the Constitution. ${ }^{140}$

In other words, the finding of a court that New Towns must open up the franchise to all residents would not impose a new burden on developers and planners to create a different form of government. The provisions on voting could still be written into land agreements, with the understanding that such provisions will not be enforced by the courts. Or, if this would foster unnecessary litigation, future covenants could specify that the franchise will be open to all residents, either from the beginning or after a certain date. Such provisions might not meet with the wholehearted approval of prospective home owners, who would desire the same amount of control over their neighborhood as they might have obtained by purchasing in a small subdivision with a small homes association that provides few or no services. This loss of power, however, appears to be a small price to pay for the benefits and amenities which a New Town homes association can provide. Moreover, if the vote is opened up only on the central homes association level, where general governing powers are exercised, the property owners could still maintain full control at the peripheral level, where the homes association's activities are limited to those traditionally carried on by small subdivision homes associations. In order to assure that courts will not find that village and cluster associations perform public functions, developers would be wise to follow the Columbia model of making village association dues voluntary and unenforceable.

139 Deed, supra note 59, $\$ 7.02$; Deed of Dedication, supra note 46, IV(11).

140 Such a case-by-case determination would be in accordance with the suggestion (see note 134 supra) that there is a "public interest" element in Marsh and perhaps in the public function area as well. 
The foregoing discussion assumes that the litigated case arises at a time when the New Town is a going operation, when it resembles an ordinary town. What changes are introduced if the case arises during the developmental period? It would be possible to argue, given the continuum of private and public, that the New Town only gradually assumes its public function status, and that during the early years it is still essentially private, and necessarily so as a pragmatic matter, if the developer is to be given the amount of influence he needs in order to protect the success of his venture. As a corollary, it could be said that the development-stage homes association is indeed a semidemocratic facade, because it is intended to serve not as a general governing body of the residents, but as an administrative device of the developer. Thus, the developer could maintain his own weighted voting power and could allocate the other votes as he deems advisable in order to assure planned development and gradual transition of control to the residents. The argument would continue: at a certain point in time the metamorphosis of the homes association from an administrative device to a governing body occurs, and at that point, it would bear sufficient resemblance to a municipal corporation to justify extension of the franchise to all residents. Such an argument -which would relegate early residents to a status of tutelage-seems unavoidable if we are committed to the building of New Towns by private developers.

This would be a departure from democratic ideals, and, if accepted, should be accompanied by safeguards. Developers should be required -by legislative or judicial action-to specify a reasonable developmental period (from seven to fifteen years, for example) which would define the outer temporal boundary of benevolent paternalism. Perhaps an administrative organ of the state is needed to monitor the development period and to set a schedule for the withering away of the developer in each New Town. On the other hand, it was suggested above $^{141}$ that the developer has an economic interest in the transfer of community control to the property owners. If things do, in fact, work out this way, the difficulties will be minimized during the developmental period. Present experiments should be studied to see how the developers behave. If it is assured that the developmental period will come to an end within a reasonable time, and if the Constitution is interpreted to provide the usual political rights after the develop-

141 See text accompanying note 71 supra. Congress ignored the recommendation of the president of the National Housing Conference when he testified that, "There is a need for a governmental unit in the locality which would have all the governmental powers, functions, and responsibilities of the New Town." Hearings, supra note 15, pt. 1, at 414-5. 
mental period, the privately developed New Town could grow and exist without a sèverè or prolonged dèprivation of puiblic rights.

\section{Gonceusion}

Although it is not claimed thăt Reston and Colümbia âre typical of all New Towns in their form of government, these two growing cities are imporfant models for future community building. Both have governments that combine public services from the county level with municipal-type services provided by private homes associations. Both New Towns have experimented with federal arrangements for their homes ássociátions, utilizing peripheral units to promote decentralized, local control over the immediate environment. The central homes associations carry on a variety of activities which affect all residents, and a strong case can be made for the position that the fourteenth amendment is applicable. If this is correct, the property basis of political participation in Reston and Columbia may violate the equal protection clause. Even if the Cônstitution is nôt relevant to these New Towns, the use of private corporations in place of municipal government raises important policy questions which have not yet received legislative consideration. 